Tropical Journal of Pharmaceutical Research, January 2017; 16 (1): 1

ISSN: $1596-5996$ (print); 1596-9827 (electronic)

(C) Pharmacotherapy Group, Faculty of Pharmacy, University of Benin, Benin City, 300001 Nigeria.

All rights reserved.

Available online at http://www.tjpr.org

http://dx.doi.org/10.4314/tjpr.v16i1.1

\title{
Erratum for "Wortmannin as targeted therapeutic agent for the treatment of triple-negative breast cancer"
}

\author{
Jian Li ${ }^{1}$, Fei Liu ${ }^{1}$ and Yang Liu ${ }^{2}$ \\ ${ }^{1}$ Department of Breast Surgery, ${ }^{2}$ Department of General Surgery, Taian City Central Hospital, Taian \\ 271000, China
}

*For correspondence:- Email: my-li@163.com Tel:+865386298057

Received: 22 May 2015 Accepted: 10 December 2015 Published: 29 January 2016

\section{Erratum}

Li et al Trop J Pharm Res 2016, 15(1): 95-99 http://dx.doi.org/10.4314/tjpr.v15i1.13

The correct names of authors and their affiliations as well as the email and telephone number of the corresponding author are those provided above.

Keywords: Ketorolac, Orthopaedic implant, Extended release, Analgesic, Anti-inflammation, Vertebral fracture

Tropical Journal of Pharmaceutical Research is indexed by Science Citation Index (SciSearch), Scopus, International Pharmaceutical Abstract, Chemical Abstracts, Embase, Index Copernicus, EBSCO, African Index Medicus, JournalSeek, Journal Citation Reports/Science Edition, Directory of Open Access Journals (DOAJ), African Journal Online, Bioline International, Open-J-Gate and Pharmacy Abstracts

\section{Open Access}

This is an Open Access article that uses a funding model which does not charge readers or their institutions for access and distributed under the terms of the Creative Commons Attribution
License (http://creativecommons.org/licenses/by 14.0) and the Budapest Open Access Initiative (http://www.budapestopenaccessinitiative.org/rea d), which permit unrestricted use, distribution, and reproduction in any medium, provided the original work is properly credited. 